J. Gen. Appl. Microbiol., 52, 159-167 (2006)

Full Paper

\title{
Factors affecting the adsorption of bacteriocins ST194BZ and ST23LD to Lactobacillus sakei and Enterococcus sp.
}

\author{
Svetoslav Dimitrov Todorov, ${ }^{1}$ Martina Meincken, ${ }^{2}$ and Leon Milner Theodore Dicks ${ }^{1, *}$ \\ ${ }^{1}$ Department of Microbiology, Stellenbosch University, 7600 Stellenbosch, South Africa \\ ${ }^{2}$ Institute of Polymer Science, University of Stellenbosch, 7600 Stellenbosch, South Africa
}

(Received October 25, 2005; Accepted March 10, 2006)

\begin{abstract}
Bacteriocins ST194BZ and ST23LD, produced by Lactobacillus plantarum, inhibit Gram-positive and Gram-negative bacteria. Images obtained by atomic force microscopy showed clear signs of membrane damage of Lactobacillus sakei, accompanied by the leakage of DNA and $\beta$-galactosidase. Adsorption of the bacteriocins to cells was increased when cells were treated with buffers at pH values above neutral. An increase in bacteriocin ST194BZ adsorption to cells of Enterococcus sp. and $L$. sakei was observed with an increase in incubation temperatures, but at different rates for the two species. Treatment of the two species with various inorganic salts and solvents gave different results regarding the adsorption of the two bacteriocins. In general, pre-treatment of the two sensitive cells with Triton X-100, Triton X-114 and chloroform increased the adsorption of the two bacteriocins. Increased adsorption of bacteriocin ST23LD to $L$. sakei was recorded when the cells were pre-treated with Tris and $\mathrm{NH}_{4}$-citrate. Treatment of Enterococcus sp. and $L$. sakei with Na-EDTA and SDS decreased the adsorption of the two bacteriocins. Variable results were recorded with inorganic salts.
\end{abstract}

Key Words__adsorption; bacteriocins ST194BZ and ST23LD; Lactobacillus plantarum

\section{Introduction}

The ability of lactic acid bacteria (LAB) to inhibit the growth of undesirable bacteria is well known. Inhibition may be due to production of organic acids, diacetyl, $\mathrm{H}_{2} \mathrm{O}_{2}$, or bacteriocins. Bacteriocins are ribosomal synthesized polypeptides with activity against bacteria closely related to the producer strain (Klaenhammer, 1988). These peptides are divided into three categories, i.e. (i) peptides with a narrow inhibitory spectrum, affecting only closely-related species, (ii) peptides inhibitory to Gram-positive bacteria, including food-borne pathogens (Klaenhammer, 1988), and (iii)

\footnotetext{
* Address reprint requests to: Prof Leon Milner Theodore Dicks, Department of Microbiology, University of Stellenbosch, 7600 Stellenbosch, South Africa.

E-mail: LMTD@sun.ac.za
}

peptides with an unusual spectrum of activity, including that against Gram-negative bacteria (Piard and Desmazeaud, 1992; Todorov and Dicks, 2005c), viruses (Serkedjieva et al., 2000; Todorov et al., 2005; Wachsman et al., 1999) and yeast (Okkers et al., 1999).

Lactobacillus plantarum ST194BZ, isolated from boza, a cereal-based fermented beverage from Bulgaria, produces two bacteriocins, viz. ST194BZ(a) of $3.3 \mathrm{kDa}$ and ST194BZ(b) of $14.0 \mathrm{kDa}$ (Todorov and Dicks, 2006). A combination of the two bacteriocins inhibits the growth of Lactobacillus casei, Lactobacillus casei, Lactobacillus delbrueckii subsp. bulgaricus, Enterococcus faecalis, Escherichia coli, Enterobacter cloacae, and Pseudomonas aeruginosa. A maximum total bacteriocin activity of $12,800 \mathrm{AU} / \mathrm{ml}$ was recorded in MRS broth (Todorov and Dicks, 2005b).

Bacteriocins ST194BZ(a) and ST194BZ(b) withstand $20 \mathrm{~min}$ at $121^{\circ} \mathrm{C}$ and incubation at $\mathrm{pH} 2-10$, but 
Table 1. Changes in the number of viable cells recorded after $1 \mathrm{~h}$ in the presence of bacteriocins ST194BZ and ST23LD.

\begin{tabular}{llll}
\hline & & \multicolumn{2}{c}{$\begin{array}{c}\text { After } 1 \mathrm{~h} \text { in the presence of } \\
2,133 \mathrm{AU} / \mathrm{ml}\end{array}$} \\
\hline Test microorganism & Before treatment & $\begin{array}{l}\text { Bacteriocin } \\
\text { ST194BZ }\end{array}$ & $\begin{array}{l}\text { Bacteriocin } \\
\text { ST23LD }\end{array}$ \\
\hline Enterococcus sp. HKLHS & $8.7 \times 10^{9}$ & $1.4 \times 10^{7}$ & $3.4 \times 10^{7}$ \\
L. sakei DSM 20017 & $1.0 \times 10^{9}$ & $1.2 \times 10^{8}$ & $2.5 \times 10^{8}$ \\
\hline
\end{tabular}

are inactivated when treated with proteolytic enzymes such as pepsin, papain, $\alpha$-chymotrypsin, trypsin and Proteinase K (Todorov and Dicks, 2005b). The mechanism of activity is bactericidal, as determined against L. casei LHS (Todorov and Dicks, 2005b, 2006).

L. plantarum ST23LD was isolated from the brine of spoiled black olives and produces two bacteriocins (ST23LD(a) and ST23LD(b)) of approximately 3.0 and $14.0 \mathrm{kDa}$, respectively (Todorov and Dicks, 2005a). The peptides inhibit the growth of Gram-positive bacteria (E. faecalis, L. casei, and Streptococcus pneumoniae) and $E$. coli and $P$. aeruginosa. The combined maximum activity recorded for the two peptides was 25,600 AU/ml (Todorov and Dicks, 2005a).

Bacteriocins ST23LD(a) and ST23LD(b) withstand $20 \mathrm{~min}$ at $121^{\circ} \mathrm{C}$ and incubation at $\mathrm{pH} 2-10$, but are inactivated when treated with papain, $\alpha$-chymotrypsin, trypsin and Proteinase K. The mechanism of activity is bactericidal, as determined against $L$. casei LHS (Todorov and Dicks, 2005a).

A limited number of papers have been published on the adsorption of bacteriocins to target (sensitive) cells. Pediocin N5p, produced by Pediococcus pentosaceus, adsorbed selectively to Gram-positive and Gram-negative bacteria (Manca de Nadra et al., 1998). The presence of $\mathrm{Mg}^{2+}$ and $\mathrm{Mn}^{2+}$ increased pediocin N5p binding to $P$. pentosaceus by $80 \%$ and $100 \%$, respectively. Treatment of the target strain with $1 \%$ SDS increased the adsorption of pediocin N5p by $25 \%$ (Manca de Nadra et al., 1998). Adsorption of buchnericin LB, produced by Lactobacillus buchneri, is influenced by $\mathrm{pH}$ and not temperature or contact time (Yildirim et al., 2002). Anions and lipoteichoic acid reduced or inhibited the adsorption of buchnericin LB to the target cells. Treatment of cells with detergents or organic solvents had no effect on the adsorption of buchnericin LB.

In this study, the factors affecting the adsorption of bacteriocins ST194BZ(a), ST194BZ(b), ST23LD(a), and ST23LD(b) to target bacteria were determined. The bacteriocins were not separated and will be referred to as ST194BZ and ST23LD.

\section{Materials and Methods}

Growth conditions and preparation of bacteriocins ST194BZ and ST23LD. Lactobacillus plantarum ST194BZ and ST23LD were grown in MRS broth (Oxoid, Ltd., Basingstoke, Hampshire, England). The other strains used in this study (Table 1) were grown in MRS broth (Oxoid) or BHI broth (Oxoid), at temperatures indicated in the respective culture collection catalogues. All strains were stored at $-80^{\circ} \mathrm{C}$ in MRS or $\mathrm{BHI}$ broth supplemented with $15 \%(\mathrm{v} / \mathrm{v})$ glycerol.

L. plantarum ST194BZ and ST23LD were inoculated ( $2 \%, v / v$, respectively) into $100 \mathrm{ml}$ MRS broth and incubated at $30^{\circ} \mathrm{C}$ for $24 \mathrm{~h}$. The cells were harvested $\left(1,000 \times \mathrm{g}, 15 \mathrm{~min}, 4^{\circ} \mathrm{C}\right)$, the $\mathrm{pH}$ of the cell-free supernatants adjusted to 6.0 with sterile $1 \mathrm{M} \mathrm{NaOH}$, heated for $10 \mathrm{~min}$ at $80^{\circ} \mathrm{C}$, and then filter-sterilized (nitrocellulose membrane, $0.20 \mu \mathrm{m}$ pore size, Minisart ${ }^{\circledR}$, Sartorius).

Bacteriocin bioassay. Bacteriocin activity tests were performed on cell-free supernatants by using the agar-spot test and the well-diffusion method, respectively (Todorov and Dicks, 2005c). Cell-free supernatants were adjusted to $\mathrm{pH} 6.0$ with sterile $1 \mathrm{M} \mathrm{NaOH}$ before testing. Target microorganisms (Table 1) were cultured in $\mathrm{BHI}$ (non-lactic acid bacteria) or MRS (lactic acid bacteria). Antimicrobial activity was expressed as arbitrary units $(\mathrm{AU}) / \mathrm{ml}$, calculated as follows: $a^{b} \times 100$, where " $a$ " represents the dilution factor and " $b$ " the last dilution that produces an inhibition zone of at least 2 $\mathrm{mm}$ in diameter. Activity was expressed per $\mathrm{ml}$ by multiplication with 100 (Todorov and Dicks, 2005c).

Effect of bacteriocins ST194BZ and ST23LD on cell 
growth. Twenty milliliters filter-sterilized cell-free supernatant containing bacteriocin ST194BZ $(12,800 \mathrm{AU} /$ $\mathrm{ml}, \mathrm{pH}$ 6.0), was added to $100 \mathrm{ml} 3 \mathrm{~h}$-old cultures $\left(\mathrm{OD}_{600}=0.1-0.2\right)$ of Enterococcus sp. HKLHS and $L$. sakei DSM 20017, respectively. Optical density readings were taken at $600 \mathrm{~nm}$, hourly for $13 \mathrm{~h}$. The experiment was repeated with bacteriocin ST23LD $(12,800$ $\mathrm{AU} / \mathrm{ml}, \mathrm{pH}$ 6.0). In a similar experiment, the effect of the two bacteriocins was tested on stationary-phase cells $\left(\mathrm{OD}_{600}=1.2-1.5\right)$ of Enterococcus sp. HKLHS and L. sakei DSM 20017.

Effect of bacteriocins ST194BZ and ST23LD on the cell morphology of L. sakei DSM 20017. L. sakei DSM 20017 was grown in $10 \mathrm{ml}$ MRS broth at $37^{\circ} \mathrm{C}$ for $18 \mathrm{~h}$. The cells were harvested $\left(8,000 \times \mathrm{g}, 10 \mathrm{~min}, 4^{\circ} \mathrm{C}\right)$ and washed 5 times with $10 \mathrm{ml}$ sterile distilled water. The cells were then re-suspended in $20 \mathrm{ml}$ sterile distilled water and divided into two equal volumes. Bacteriocins ST194BZ and ST23LD were each diluted with sterile distilled water to $12,800 \mathrm{AU} / \mathrm{ml}$, filter-sterilized and adjusted to $\mathrm{pH} 6.0$ with $1 \mathrm{M} \mathrm{NaOH}$. To each of the cell suspensions $10 \mathrm{ml}$ of a bacteriocin was added (final activity $=6,400 \mathrm{AU} / \mathrm{ml}$ ) and incubated for $1 \mathrm{~h}$ at $4^{\circ} \mathrm{C}$. The cells were then harvested $(8,000 \times \mathrm{g}, 10 \mathrm{~min}$, $4^{\circ} \mathrm{C}$ ) and washed five times with $10 \mathrm{ml}$ sterile distilled water. The cells were suspended in $1 \mathrm{ml}$ sterile distilled water and visualized by atomic force microscopy (AFM) (Multimode AFM from Veeco, Santa Barbara, USA). The experiment was repeated with sterile distilled water (no bacteriocins) as a control. Cell suspensions were applied to a freshly cleaved mica surface and allowed to dry for $5 \mathrm{~min}$ before being subjected to AFM. All images were obtained in air and with tapping mode. A silicon non-contact cantilever from Nanosensors (Neuchatel, Switzerland) with a resonance frequency of $160 \mathrm{kHz}$ and a spring constant of approximately $50 \mathrm{~N} / \mathrm{m}$ was used. Height and size information was acquired by using the imaging software from Veeco.

Effect of bacteriocins ST194BZ and ST23LD on cell permeability. Log-phase cells $\left(\mathrm{OD}_{600}=0.8-1.0\right)$ of Enterococcus sp. HKLHS $(10 \mathrm{ml})$ were harvested $\left(10,000 \times g, 15 \mathrm{~min}, 4^{\circ} \mathrm{C}\right)$, washed twice with $10 \mathrm{ml}$ sterile $5 \mathrm{~mm}$ phosphate buffer ( $\mathrm{pH} 6.5$ ), and re-suspended in $20 \mathrm{ml} 5 \mathrm{~mm}$ phosphate buffer $(\mathrm{pH} 6.5)$. The cell suspension was then divided into two equal volumes. One of the cell suspensions was treated with $1.0 \mathrm{ml}$ bacteriocin ST194BZ $(12,800 \mathrm{AU} / \mathrm{ml})$ and the other with $1.0 \mathrm{ml}$ bacteriocin ST23LD $(12,800 \mathrm{AU} / \mathrm{ml})$. The final concentration of the two bacteriocins were 1,280 AU/ $\mathrm{ml}$. After $1 \mathrm{~h}$ of incubation at $37^{\circ} \mathrm{C}$, the cells were harvested $\left(10,000 \times g, 15 \mathrm{~min}, 4^{\circ} \mathrm{C}\right)$ and the supernatant filtered through a $0.20 \mu \mathrm{m}$ nitrocellulose membrane (Minisart $^{\circledR}$, Sartorius). Absorbancy readings of the cellfree supernatant were recorded at $260 \mathrm{~nm}$. The experiment was repeated with L. sakei DSM 20017 as a sensitive strain. Controls were Enterococcus sp. HKLHS and L. sakei DSM 20017 suspended in $5 \mathrm{~mm}$ phosphate buffer, but without bacteriocins, and in the same buffer containing bacteriocins ST194BZ and ST23LD, respectively, but without cells.

In a separate experiment, the level of $\beta$-galactosidase secreted from damaged cells was determined. Ten milliliters of a log-phase culture of Enterococcus sp. HKLHS $\left(\mathrm{OD}_{600}=0.8-1.0\right)$ was harvested, the cells washed twice with $10 \mathrm{ml} 0.03 \mathrm{M}$ sodium phosphate buffer ( $\mathrm{pH} \mathrm{6.5),} \mathrm{the} \mathrm{pellet} \mathrm{re-suspended} \mathrm{into} 4 \mathrm{ml}$ of the same buffer and divided into two equal volumes. One of the cell suspensions was treated with bacteriocin ST194BZ and the other with bacteriocin ST23LD (final concentrations $=6,400 \mathrm{AU} / \mathrm{ml}$ ). After $5 \mathrm{~min}$ of incubation at $25^{\circ} \mathrm{C}, 0.2 \mathrm{ml} 0.1 \mathrm{M} \mathrm{ONPG}(O$-nitrophenyl- $\beta$-Dgalactopyranoside), dissolved in $0.03 \mathrm{M}$ sodium phosphate buffer ( $\mathrm{pH}$ 6.8), was added to each of the cell suspensions and the cells incubated for $10 \mathrm{~min}$ at $37^{\circ} \mathrm{C}$. The $\beta$-galactosidase reaction was stopped by adding $2.0 \mathrm{ml} 0.1 \mathrm{M}$ sodium carbonate. The cells were harvested $\left(10,000 \times g, 15 \mathrm{~min}, 25^{\circ} \mathrm{C}\right)$ and absorbance readings of the cell-free supernatants recorded at $420 \mathrm{~nm}$. The experiment was repeated with $L$. sakei DSM 20017. Controls were cells of Enterococcus sp. HKLHS and L. sakei DSM 20017 prepared the same way, but not treated with bacteriocins ST194BZ or ST23LD (Hsu et al., 2005; Nagy et al., 2001).

Adsorption of bacteriocins ST194BZ and ST23LD to target cells. Adsorption of bacteriocins ST194BZ and ST23LD to target cells was performed according to the method described by Yildirim et al. (2002). The target strains (Table 1) were grown overnight in $10 \mathrm{ml}$ MRS or $\mathrm{BHI}$ broth at $30^{\circ} \mathrm{C}$ or $37^{\circ} \mathrm{C}$ and then harvested $\left(10,000 \times g, 15 \mathrm{~min}, 4^{\circ} \mathrm{C}\right)$. The cells were washed twice with $10 \mathrm{ml}$ sterile $5 \mathrm{~mm}$ phosphate buffer $(\mathrm{pH} \mathrm{6.5)}$ and re-suspended in the original volume in the same buffer. Each cell suspension $(0.7 \mathrm{ml})$ was treated with $0.7 \mathrm{ml}$ bacteriocin ST194BZ $(12,800 \mathrm{AU} / \mathrm{ml})$ and $0.7 \mathrm{ml}$ bacteriocin ST23LD $(12,800 \mathrm{AU} / \mathrm{ml})$, respectively, and incubated for $1 \mathrm{~h}$ at $37^{\circ} \mathrm{C}$. Cells were then harvested $\left(10,000 \times \mathrm{g}, 15 \mathrm{~min}, 25^{\circ} \mathrm{C}\right)$ and the activity of unbound 
bacteriocins in the supernatant determined as described before.

The percentage adsorption of bacteriocins ST194BZ and ST23LD to the target cells was calculated according to the following formula:

$$
\begin{gathered}
\text { \%adsorption }=100 \\
-\left(\frac{\text { bacteriocin activity after treatment }}{\text { original bacteriocin activity }} \times 100\right)
\end{gathered}
$$

Effect of $\mathrm{pH}$ and temperature on the adsorption of bacteriocins ST194BZ and ST23LD. Bacteriocin ST194BZ $(12,800 \mathrm{AU} / \mathrm{ml})$ was added to Enterococcus sp. HKLHS and L. sakei DSM 20017, respectively, to a final concentration of $6,400 \mathrm{AU} / \mathrm{ml}$. The cells were incubated for $1 \mathrm{~h}$ at $4,10,25,30,37,45$, and $60^{\circ} \mathrm{C}$ and, in a separate experiment, at $\mathrm{pH} 2.0,4.0,6.0,8.0$, and 10.0. The cells were then harvested $(10,000 \times g, 15$ $\min , 25^{\circ} \mathrm{C}$ ), the $\mathrm{pH}$ of the cell-free supernatant adjusted to 6.0 with sterile $1 \mathrm{~m} \mathrm{NaOH}$ and bacteriocin activity determined as described before. The experiment was repeated with bacteriocin ST23LD $(12,800$ $\mathrm{AU} / \mathrm{ml}$ ).

Effect of SDS, inorganic salts and organic compounds on the adsorption of bacteriocins ST194BZ and ST23LD to target cells. Eighteen-hour-old cells of Enterococcus sp. HKLHS and L. sakei DSM 20017 were treated with $1 \%(\mathrm{w} / \mathrm{v}) \mathrm{NaCl}, \mathrm{K}_{2} \mathrm{HPO}_{4}, \mathrm{KH}_{2} \mathrm{PO}_{4}$, $\mathrm{MgCl}_{2}, \mathrm{KCl}, \mathrm{KI}$, Tris, $\left(\mathrm{NH}_{4}\right)_{3} \mathrm{C}_{6} \mathrm{H}_{5} \mathrm{O}_{7}, \mathrm{CH}_{3} \mathrm{COONa}$, $\mathrm{Na}_{2} \mathrm{CO}_{3}$, EDTA $\left(\mathrm{C}_{10} \mathrm{H}_{16} \mathrm{O}_{8} \mathrm{~N}_{2}\right)$, and SDS, $1 \%(\mathrm{v} / \mathrm{v})$ Triton $\mathrm{X}-100$, Triton $\mathrm{X}-114, \beta$-mercaptoethanol, and $80 \%$ ethanol, methanol, and chloroform, respectively. Bacteriocin ST194BZ $(12,800 \mathrm{AU} / \mathrm{ml})$ was added to the treated cells, as described before, and incubated for $1 \mathrm{~h}$ at $37^{\circ} \mathrm{C}$. The cells were then harvested $(10,000 \times \mathrm{g}$, $15 \mathrm{~min}, 25^{\circ} \mathrm{C}$ ) and the activity of the bacteriocins in the cell-free supernatant determined as described before. The experiment was repeated with bacteriocin ST23LD $(12,800 \mathrm{AU} / \mathrm{ml})$.

\section{Results and Discussion}

Effect of bacteriocins ST194BZ and ST23LD on cell growth

Addition of the bacteriocins ST194BZ and ST23LD to early logarithmic-phase cells of Enterococcus sp. HKLHS or L. sakei DSM 20017 resulted in immediate growth inhibition for at least $10 \mathrm{~h}$ (Fig. 1). Concluded from these results, the mode of action of the two bacteriocins is bactericidal. Similar results were recorded for the two bacteriocins against $L$. casei LHS (Todorov and Dicks, 2005a, 2006), plantaricin 423 against

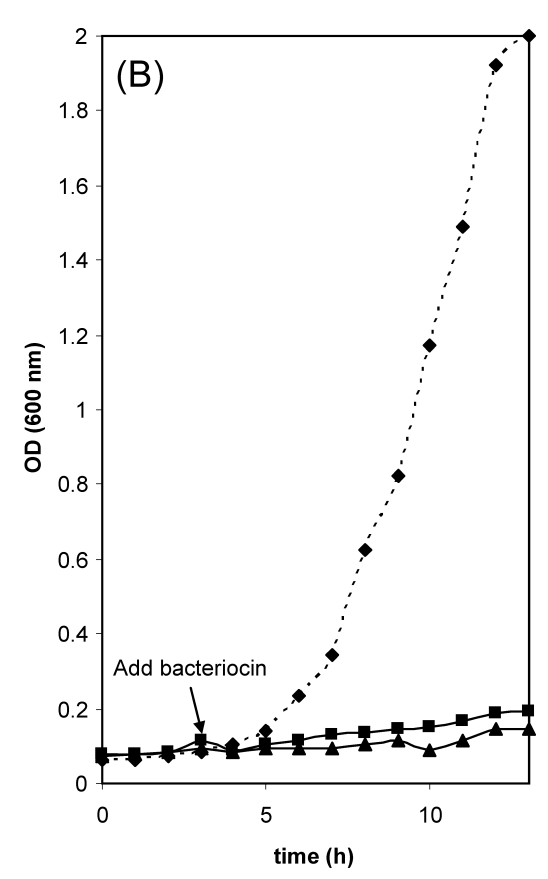

Fig. 1. Effect of bacteriocins ST194BZ and ST23LD on the growth of (A) Enterococcus sp. HKLHS and (B) L. sakei DSM 20017.

Symbols: $\boldsymbol{\star}$, in the absence of bacteriocins; $\mathbf{\square}$, in the presence of bacteriocin ST194BZ; $\boldsymbol{\Delta}$, in the presence of bacteriocin ST23LD. 


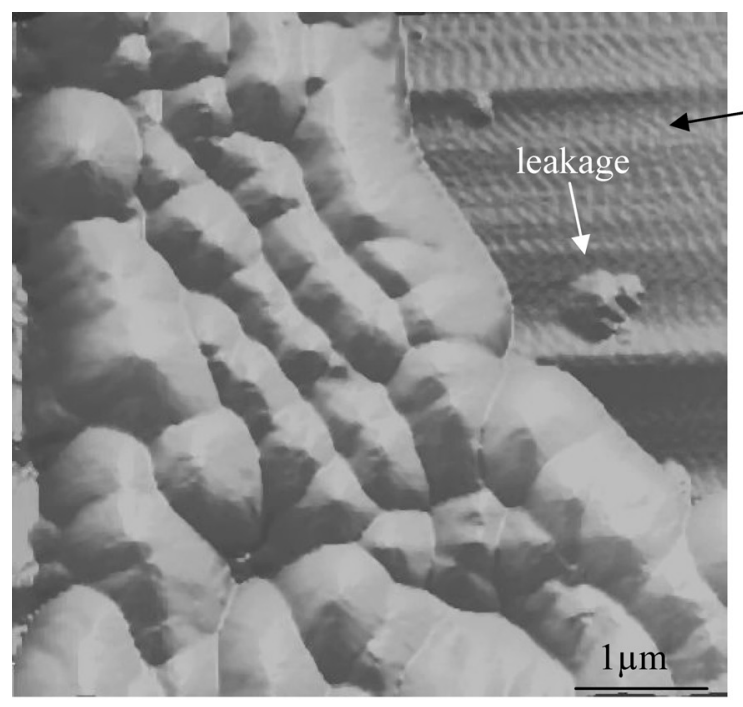

(A)

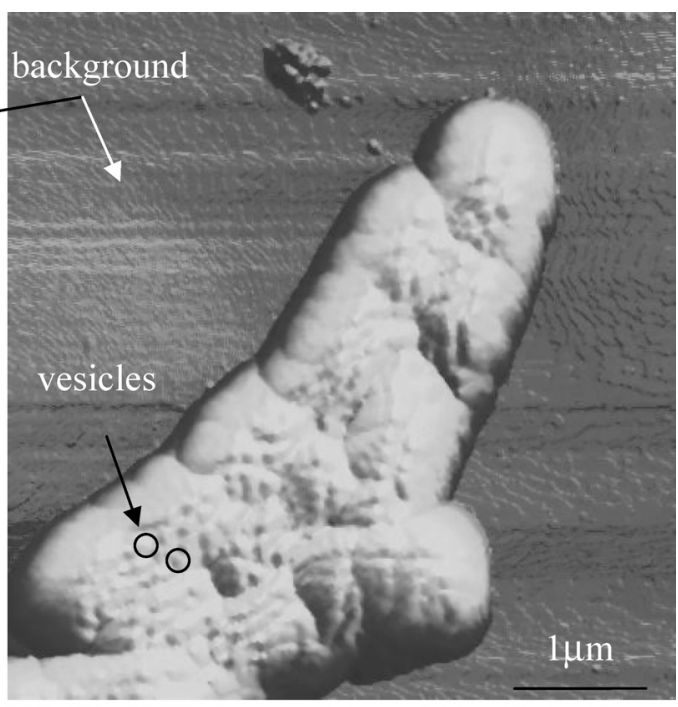

(B)

Fig. 2. Morphology of L. sakei DSM 20017 after treatment with (A) bacteriocin ST194BZ and (B) bacteriocin ST23LD.

The images were taken with an atomic force microscope. The image size is $5 \times 5 \mu \mathrm{m}$.

Oenococcus oeni 19Cl (Van Reenen et al., 1998), pediocin N5p against Pediococcus pentosaceus E5p (Manca de Nadra et al., 1998), and buchnericin LB against Listeria monocytogenes and Bacillus cereus (Yildirim et al., 2002).

Treatment of stationary-phase cells of Enterococcus sp. HKLHS and L. sakei DSM 20017 for $1 \mathrm{~h}$ with bacteriocin ST194BZ decreased the number of viable cells by 2.8 and 0.9 log cycles, respectively. Similar results were recorded for cells treated with bacteriocin ST23LD (Table 1). L. monocytogenes treated with 640, 1,280 , and 2,560 AU/ml buhnericin LB decreased by $0.8,1.92$, and 3.12 log cycles (Yildirim et al., 2002).

\section{Effect of bacteriocins ST194BZ and ST23LD on cell morphology}

Cells of L. sakei DSM 20017 treated with bacteriocins ST194BZ and ST23LD were clearly deformed, as visualized by AFM (Fig. 2). Treatment with bacteriocin ST194BZ caused the cells to collapse, accompanied by leakage of the cytoplasm from the cells (Fig. 2A). The surface of these cells appeared smooth. Treatment with bacteriocin ST23LD, on the other hand, caused vesiculation of the cell membrane with a vesicle diameter of 100-200 nm (Fig. 2B). The surface of these cells appeared granular, but the cells retained their shape. The morphology of cells treated with sterile distilled water (no bacteriocins) remained un- changed.

Effect of bacteriocins ST194BZ and ST23LD on cell membrane permeability

Enterococcus sp. HKLHS and Lactobacillus sakei DSM 20017 treated with bacteriocins ST194BZ and ST23LD resulted in the leakage of DNA and $\beta$-galactosidase (Table 2). Concluded from these results, the mode of action of bacteriocins ST194BZ and ST23LD is most probably destabilizing of the permeability of the cell membrane. Similar results have been reported for buchnericin LB (Yildirim et al., 1999, 2002) and pediocin AcH (Bhunia et al., 1991).

\section{Adsorption of bacteriocins ST194BZ and ST23LD to target cells}

Bacteriocins ST194BZ and ST23LD adsorbed to sensitive and resistant cells of Gram-positive bacteria (Table 3). Adsorption of bacteriocin ST194BZ ranged from $0 \%$ for Lactococcus lactis subsp. lactis HV219 to 50\% for L. sakei DSM 20017 and Enterococcus sp. HKLHS. Bacteriocin ST23LD adsorption ranged from $28 \%$ for L. plantarum LMG 13556 to $71 \%$ for L. sakei DSM 20017. Strains sensitive to bacteriocins ST194BZ and ST23LD revealed stronger adsorption of the peptides, compared to cells resistant to the peptide. Similar results have been reported by Yildirim et al. (2002). In the case of buhnericin LB, $100 \%$ adsorp- 
Table 2. Extracellular levels of DNA and $\beta$-galactosidase recorded after treatment of Enterococcus sp. HKLHS and L. sakei DSM 20017 with bacteriocins ST194BZ and ST23LD.

\begin{tabular}{|c|c|c|c|c|}
\hline & \multicolumn{2}{|c|}{ Absorbance at $260 \mathrm{~nm}$ (DNA detection) } & \multicolumn{2}{|c|}{$\begin{array}{c}\text { Absorbance at } 420 \mathrm{~nm} \\
\text { ( } \beta \text {-galactosidase detection) }\end{array}$} \\
\hline & $\begin{array}{l}\text { Enterococcus } \\
\text { sp. HKLHS }\end{array}$ & $\begin{array}{l}\text { L. sakei } \\
\text { DSM } 20017\end{array}$ & $\begin{array}{l}\text { Enterococcus } \\
\text { sp. HKLHS }\end{array}$ & $\begin{array}{l}\text { L. sakei } \\
\text { DSM } 20017\end{array}$ \\
\hline Treated cells & 3.00 & 3.11 & 1.20 & 1.17 \\
\hline Untreated cells & 0.46 & 0.62 & 0.12 & 0.23 \\
\hline \multirow[t]{3}{*}{ Bacteriocin ST194BZ, no cells } & 0.64 & 0.64 & 0.63 & 0.63 \\
\hline & \multicolumn{2}{|c|}{ Absorbance at $260 \mathrm{~nm}$ (DNA detection) } & \multicolumn{2}{|c|}{$\begin{array}{c}\text { Absorbance at } 420 \mathrm{~nm} \\
\text { ( } \beta \text {-galactosidase detection) }\end{array}$} \\
\hline & $\begin{array}{l}\text { Enterococcus } \\
\text { sp. HKLHS }\end{array}$ & $\begin{array}{l}\text { L. sakei } \\
\text { DSM } 20017\end{array}$ & $\begin{array}{l}\text { Enterococcus } \\
\text { sp. HKLHS }\end{array}$ & $\begin{array}{l}\text { L. sakei } \\
\text { DSM } 20017\end{array}$ \\
\hline Treated cells & 2.79 & 3.13 & 1.13 & 1.18 \\
\hline Untreated cells & 0.46 & 0.62 & 0.12 & 0.23 \\
\hline Bacteriocin ST23LD, no cells & 0.73 & 0.73 & 0.64 & 0.64 \\
\hline
\end{tabular}

Table 3. Activity spectrum of bacteriocins ST194BZ and ST23LD and their adsorption to target cells (expressed as a percentage value).

\begin{tabular}{|c|c|c|c|c|}
\hline \multirow[b]{2}{*}{ Target organism } & \multicolumn{2}{|c|}{ Bacteriocin ST194BZ } & \multicolumn{2}{|c|}{ Bacteriocin ST23LD } \\
\hline & $\begin{array}{l}\text { Sensitivity to } \\
\text { bacteriocin } \\
\text { ST194BZ }^{a}\end{array}$ & $\begin{array}{c}\text { Adsorption } \\
(\%)\end{array}$ & $\begin{array}{l}\text { Sensitivity to } \\
\text { bacteriocin } \\
\text { ST23LD }\end{array}$ & $\begin{array}{c}\text { Adsorption } \\
(\%)\end{array}$ \\
\hline Enterococcus faecalis BFE 1071 & - & 33 & + & 57 \\
\hline Enterococcus mundtii ST4SA & - & 16 & - & 43 \\
\hline Enterococcus sp. HKLHS & + & 50 & + & 57 \\
\hline Enterococcus faecalis FAIR E92 & - & 16 & - & 43 \\
\hline Lactobacillus curvatus DF38 & - & 16 & + & 57 \\
\hline Lactobacillus plantarum LMG 13556 & - & 16 & - & 28 \\
\hline Lactobacillus sakei DSM20017 & + & 50 & + & 71 \\
\hline Lactobacillus salivarius 241 & - & 16 & + & 57 \\
\hline Lactococcus lactis subsp. lactis HV219 & - & 0 & - & 43 \\
\hline Listeria innocua LMG 13568 & + & 33 & + & 57 \\
\hline Streptococcus caprinus ATCC 700066 & - & 16 & - & 43 \\
\hline
\end{tabular}

$a_{-}=$not inhibited, and $+=$inhibited by bacteriocin ST194BZ or bacteriocin ST23LD, respectively.

tion to L. plantarum, Pediococcus dextranicus, O. oeni, and $E$. faecalis have been reported (Yildirim et al., 2002). The authors also reported $100 \%$ adsorption of the peptide to a strain of Pediococcus cerevisiae insensitive to buchnericin LB. In our experiments, bacte- riocins ST194BZ and ST23LD adsorbed to the cells at levels less then 33\%. Similar results have been recorded by Manca de Nadra et al. (1998). Higher adsorption of pediocin N5p was observed to sensitive strains. Adsorption of $100 \%$ was recorded for O. oeni 
(previously Leuconostoc oenos) X2L, $80 \%$ for Lactobacillus hilgardii and $\mathrm{O}$. oeni $\mathrm{L} 10$, and $70 \%$ for L. hilgardii 6D (Manca de Nadra et al., 1998). Pediocin N5p adsorbed to resistant bacteria at levels below $20 \%$ (Manca de Nadra et al., 1998).
Effect of $\mathrm{pH}$, temperature, SDS and salts on the adsorption of bacteriocins ST194BZ and ST23LD to target cells

Optimal adsorption of bacteriocin ST194BZ to Enterococcus sp. HKLHS was recorded at $\mathrm{pH} 10.0$ (66\%).

Table 4. Effect of $\mathrm{pH}$, temperature, SDS, inorganic salts, and solvents on the adsorption of bacteriocins ST194BZ and ST23LD to target cells (expressed as a percentage value).

\begin{tabular}{|c|c|c|c|c|}
\hline & \multicolumn{2}{|c|}{ Bacteriocin ST194BZ } & \multicolumn{2}{|c|}{ Bacteriocin ST23LD } \\
\hline & $\begin{array}{l}\text { Enterococcus sp. } \\
\text { HKLHS }\end{array}$ & $\begin{array}{l}\text { L. sakei } \\
\text { DSM } 20017\end{array}$ & $\begin{array}{l}\text { Enterococcus sp. } \\
\text { HKLHS }\end{array}$ & $\begin{array}{l}\text { L. sakei } \\
\text { DSM } 20017\end{array}$ \\
\hline \multicolumn{5}{|c|}{ Effect of $\mathrm{pH}$ : } \\
\hline 2 & 33 & 50 & 71 & 57 \\
\hline 4 & 33 & 50 & 57 & 57 \\
\hline 6 & 50 & 50 & 57 & 71 \\
\hline 8 & 50 & 66 & 57 & 71 \\
\hline 10 & 66 & 66 & 57 & 71 \\
\hline \multicolumn{5}{|c|}{ Effect of temperature $\left({ }^{\circ} \mathrm{C}\right)$ : } \\
\hline 4 & 33 & 50 & 57 & 71 \\
\hline 10 & 33 & 50 & 71 & 71 \\
\hline 25 & 33 & 50 & 71 & 57 \\
\hline 30 & 50 & 50 & 57 & 57 \\
\hline 37 & 50 & 50 & 57 & 71 \\
\hline 45 & 33 & 66 & 57 & 86 \\
\hline 60 & 33 & 83 & 57 & 86 \\
\hline
\end{tabular}

Effect of SDS,

inorganic salts and solvents:

\begin{tabular}{|c|c|c|c|c|}
\hline $\mathrm{Na}$-acetate & 50 & 66 & 42 & 71 \\
\hline $\mathrm{Na}_{2} \mathrm{CO}_{3}$ & 50 & 66 & 42 & 71 \\
\hline $\mathrm{EDTA}(\mathrm{Na})$ & 33 & 33 & 42 & 57 \\
\hline SDS & 33 & 33 & 42 & 57 \\
\hline Triton X-100 & 83 & 83 & 71 & 86 \\
\hline Triton X-114 & 83 & 100 & 86 & 100 \\
\hline$\beta$-Mercaptoethanol & 66 & 50 & 71 & 71 \\
\hline $80 \%$ Ethanol & 66 & 66 & 57 & 71 \\
\hline Methanol & 50 & 50 & 42 & 71 \\
\hline Chloroform & 66 & 100 & 71 & 86 \\
\hline $\mathrm{NaCl}$ & 33 & 50 & 42 & 71 \\
\hline $\mathrm{K}_{2} \mathrm{HPO}_{4}$ & 50 & 16 & 42 & 71 \\
\hline $\mathrm{KH}_{2} \mathrm{PO}_{4}$ & 33 & 33 & 57 & 71 \\
\hline $\mathrm{MgCl}_{2}$ & 33 & 50 & 42 & 71 \\
\hline $\mathrm{KCl}$ & 50 & 33 & 42 & 71 \\
\hline $\mathrm{KI}$ & 50 & 33 & 28 & 71 \\
\hline Tris & 50 & 50 & 57 & 86 \\
\hline $\mathrm{NH}_{4}$-citrate & 50 & 50 & 42 & 86 \\
\hline Control (not treated) & 50 & 50 & 57 & 71 \\
\hline
\end{tabular}


At pH 6.0 and 8.0 only $50 \%$ adsorption was detected (Table 4). In the case of L. sakei DSM 20017, optimal adsorption of bacteriocin ST194BZ was recorded between $\mathrm{pH} 8.0$ and 10.0. Similar results were recorded for bacteriocin ST23LD. Optimal adsorption of bacteriocin ST23LD to Enterococcus sp. HKLHS (57\%) was recorded at $\mathrm{pH} 4.0$ to 10.0. The best adsorption (71\%) to $L$. sakei DSM 20017 was recorded at $\mathrm{pH} 6.0$ to 10.0. In the case of buchnericin LB, optimal levels of adsorption to $L$. plantarum were recorded at $\mathrm{pH} 5.0$ 8.0 (Yildirim et al., 2002).

Incubation temperature has a significant effect on the adsorption of bacteriocins ST194BZ and ST23LD to Enterococcus sp. HKLHS and L. sakei DSM 20017 (Table 4). Higher adsorption of bacteriocin ST194BZ to cells of Enterococcus sp. HKLHS (50\%) and to $L$. sakei DSM 20017 (83\%) was recorded at $30^{\circ} \mathrm{C}$ or $37^{\circ} \mathrm{C}$ and $60^{\circ} \mathrm{C}$, respectively. In the case of bacteriocin ST23LD, higher adsorption was observed at $10^{\circ} \mathrm{C}$ or $25^{\circ} \mathrm{C}$ to cells of Enterococcus sp. HKLHS (71\%) and at $45^{\circ} \mathrm{C}$ or $60^{\circ} \mathrm{C}$ to cells of L. sakei DSM 20017 (86\%). Reasons for the latter differences in adsorption rates are not known, but may be due to specific interaction between bacteriocins ST194BZ and ST23LD and the target cells. In the case of buchnericin LB, identical adsorption to cells of $L$. plantarum was recorded after treatment at $0,10,25,50$, and $80^{\circ} \mathrm{C}$ (Yildirim et al., 2002).

Reduction in adsorption of bacteriocin ST194BZ to Enterococcus sp. HKLHS was observed when cells were treated with $\mathrm{NaCl}, \mathrm{KH}_{2} \mathrm{PO}_{4}, \mathrm{MgCl}_{2}$, EDTA, and SDS (Table 4). Treatment of the cells with Na-acetate, $\mathrm{Na}_{2} \mathrm{CO}_{3}$, methanol, $\mathrm{K}_{2} \mathrm{HPO}_{4}, \mathrm{KCl}, \mathrm{KI}$, Tris, and $\mathrm{NH}_{4^{-}}$ citrate yielded the same levels of adsorption compared to untreated cells of Enterococcus sp. HKLHS (Table 4). An increase in the adsorption of bacteriocin ST194BZ to Enterococcus sp. HKLHS was observed in the presence of Triton X-100, Triton X-114, $\beta$-mercaptoethanol, $80 \%$ ethanol, and chloroform (Table 4).

Cells of L. sakei DSM 20017 treated with EDTA, SDS, $\mathrm{K}_{2} \mathrm{HPO}_{4}, \mathrm{KH}_{2} \mathrm{PO}_{4}, \mathrm{KCl}$, and $\mathrm{KI}$ led to a reduction in bacteriocin ST194BZ adsorption (Table 4). No change in adsorption was observed in the presence of $\beta$-mercaptoethanol, methanol, $\mathrm{NaCl}, \mathrm{MgCl}_{2}$, Tris, or $\mathrm{NH}_{4}$-citrate, whereas an increase in adsorption was observed in the presence of $\mathrm{Na}$-acetate, $\mathrm{Na}_{2} \mathrm{CO}_{3}$, Triton $\mathrm{X}-100$, Triton $\mathrm{X}-114,80 \%$ ethanol, and chloroform (Table 4).

Reduction in adsorption of bacteriocin ST23LD to
Enterococcus sp. HKLHS was observed when cells were treated with $\mathrm{Na}$-acetate, $\mathrm{Na}_{2} \mathrm{CO}_{3}$, EDTA, SDS, methanol, $\mathrm{NaCl}, \mathrm{K}_{2} \mathrm{HPO}_{4}, \mathrm{MgCl}_{2}, \mathrm{KCl}, \mathrm{KI}$, and $\mathrm{NH}_{4}$-citrate (Table 4). Treatment of the cells with $80 \%$ ethanol, $\mathrm{KH}_{2} \mathrm{PO}_{4}$, and Tris yielded the same levels of adsorption compared to untreated cells of Enterococcus sp. HKLHS (Table 4). An increase in the adsorption of bacteriocin ST194BZ to Enterococcus sp. HKLHS was observed in the presence of Triton X-100, Triton X114, $\beta$-mercaptoethanol, and chloroform (Table 4).

Cells of L. sakei DSM 20017 treated with EDTA and SDS led to a reduction in bacteriocin ST23LD adsorption (Table 4). No change in adsorption was observed in the presence of $\mathrm{Na}$-acetate, $\mathrm{Na}_{2} \mathrm{CO}_{3}, \beta$-mercaptoethanol, $80 \%$ ethanol, methanol, $\mathrm{NaCl}, \mathrm{K}_{2} \mathrm{HPO}_{4}$, $\mathrm{KH}_{2} \mathrm{PO}_{4}, \mathrm{MgCl}_{2}, \mathrm{KCl}$, or $\mathrm{KI}$, whereas an increase in adsorption was observed in the presence of Triton X-100, Triton X-114, chloroform, Tris, and $\mathrm{NH}_{4}$-citrate (Table 4).

Adsorption of buchnericin $\mathrm{LB}$ to $L$. plantarum was reduced by $\mathrm{NaCl}, \mathrm{NH}_{4} \mathrm{Cl}, \mathrm{MgCl}_{2}, \mathrm{KCl}, \mathrm{KI}$, and Tris. Treatment of cells with $\mathrm{NH}_{4}$-citrate, $\mathrm{Na}$-acetate, $\mathrm{NaCO}_{3}$, EDTA, SDS, Triton-X, 2-mercaptoethanol, $80 \%$ ethanol, and $80 \%$ methanol had no effect on adsorption of buchnericin LB to L. plantarum (Yildirim et al., 2002).

The adsorption of pediocin N5p to $P$. pentosaceus $\mathrm{E} 5 \mathrm{p}$ increased in the presence of $\mathrm{MgCl}_{2}, \mathrm{MgSO}_{4}$, $\mathrm{MnCl}_{2}$, and $\mathrm{MnSO}_{4}$, whereas $\mathrm{NaCl}, \mathrm{KCl}, \mathrm{KI}, \mathrm{NH}_{4} \mathrm{Cl}$, $\mathrm{CaCl}_{2}, \mathrm{Na}_{3} \mathrm{PO}_{4}, \mathrm{Na}_{2} \mathrm{SO}_{4}$, EDTA, and ethanol had no affect on its adsorption (Manca de Nadra et al., 1998). Organic salts and $\mathrm{Na}$-acetate reduced pediocin N5p adsorption to the target cells. Adsorption of pediocin N5p increased by $25 \%$ in the presence of SDS (Manca de Nadra et al., 1998).

\section{Acknowledgments}

This research was supported by the National Research Foundation (NRF), South Africa.

\section{References}

Bhunia, A., Johnson, M. C., Ray, B., and Kalchanand, N. (1991) Mode of action of pediocin AcH from Pediococcus acidilactici $\mathrm{H}$ on sensitive bacterial strains. J. Appl. Bacteriol., 70, 25-33.

Hsu, C. A., Yu, R. C., and Chou, C. C. (2005) Production of $\beta$ galactosidase by bifidobacteria as influenced by various culture conditions. Int. J. Food Microbiol., 104, 197-206.

Klaenhammer, T. R. (1988) Bacteriocins of lactic acid bacteria. Biochimie, 70, 337-349.

Manca de Nadra, M. C., Sandino de Lamelas, D., and Strasser 
de Saad, A. M. (1998) Pediocin N5p from Pediococcus pentosaceus: Adsorption on bacterial strains. Int. J. Food Microbiol., 39, 79-85.

Nagy, Z., Kiss, T., Szentirmai, A., and Biro, S. (2001) $\beta$-Galactosidase of Penicillium chrysogenum: Production, purification, and characterization of the enzyme. Prot. Express. Purific., 21, 24-29.

Okkers, D. J., Dicks, L. M. T., Silvester, M., Joubert, J. J., and Odendaal, H. J. (1999) Characterization of pediocin TV35b, a bacteriocin-like peptide isolated from Lactobacillus pentosus with a fungistatic effect on Candida albicans. J. Appl. Microbiol., 87, 726-734.

Piard, J. C. and Desmazeaud, M. (1992) Inhibiting factors produced by lactic acid bacteria. 2. Bacteriocins and other antibacterial substances. Lait, 72, 113-142.

Serkedjieva, J., Danova, S., and Ivanova, I. (2000) Anti-influenza virus activity of a bacteriocin produced by Lactobacillus delbrueckii. Appl. Biochem. Biotechnol., 88, 285295.

Todorov, S. D. and Dicks, L. M. T. (2005a) Characterization of bacteriocins produced by lactic acid bacteria isolated from spoiled black olives. J. Basic Microbiol., 45, 312-322.

Todorov, S. D. and Dicks, L. M. T. (2005b) Effect of growth medium on bacteriocin production by Lactobacillus plantarum ST194BZ, a strain isolated from boza. Food Technol. Biotechnol., 43, 165-173.

Todorov, S. D. and Dicks, L. M. T. (2005c) Lactobacillus plan- tarum isolated from molasses produces bacteriocins active against Gram-negative bacteria. Enzyme Microb. Technol., 36, 318-326.

Todorov, S. D. and Dicks, L. M. T. (2006) Screening for bacteriocin producer lactic acid bacteria from boza, a traditional cereal beverage from Bulgaria. Comparison of the bacteriocins. Process Biochem., 41, 11-19.

Todorov, S. D., Wachsman, M. B., Knoetze, H., Meincken, M., and Dicks, L. M. T. (2005) An antibacterial and antiviral peptide produced by Enterococcus mundtii ST4V isolated from soy beans. Int. J. Antim. Agents, 25, 508-513.

Van Reenen, C. A., Dicks, L. M. T., and Chikindas, M. L. (1998) Isolation, purification and partial characterization of plantaricin 423, a bacteriocin produced by Lactobacillus plantarum. J. Appl. Microbiol., 84, 1131-1137.

Wachsman, M. B., Farías, M. E., Takeda, E., Sesma, F., De Ruiz Holdago, A., De Torres, R. A., and Coto, C. E. (1999) Antiviral activity of enterocin CRL35 against herpes viruses. Int. J. Antimicrob. Agents, 12, 293-299.

Yildirim, Z., Avşar, Y. K., and Yildirim, M. (2002) Factors affecting the adsorption of buchnericin LB, a bacteriocin produced by Lactobacillus buchneri. Microbiol. Res., 157, 103-107.

Yildirim, Z., Johnson, M. G., and Winters, D. K. (1999) Purification and mode of action of bifidocin $B$ produced by Bifidobacterium bifidum NCFB 1454. J. Appl. Microbiol., 86, 45-54. 